Versión "postprint" del documento publicado en:

Rodríguez Ortega, Vicente. Urban Segregation, Game Arcades and Codified Porn: Representations of Youth in Madrid (1980-1995). Journal of Urban Cultural Studies, Vol. 3, N. 2 (2016), pp. 189-205

(C) Intellect 
VICENTE RODRÍGUEZ ORTEGA

Universidad Carlos III

\section{Urban segregation, game arcades and codified porn: Representations of youth in Madrid (1980-1995)}

\begin{abstract}
This article studies how Spanish film depicts the everyday life of youth from the beginnings of democracy to the mid-1990s. I start off with youthcentred films from the early 1980s that captured previously censored occurrences of everyday living, displaying a commitment to the representation of social reality. I then move on to cinematic works stemming from a post-1992 ideological 'present-centredness'. First, I focus on the relationship between subject and urban environment since it is one of the key representational strategies in portraying the unprecedented transformations in Spanish society during this time period. Second, I analyse the emergence of audio-visual forms of consumption and how they relate to the leisurely practices of youths as they navigate the cityscape. Finally, I explore how young people interact with the
\end{abstract}

\section{KEYWORDS}

cityscape

Spanish society Spanish film urban audio-visual technologies Transition 1992 youth 
1. There are different periodizations of the Spanish Transition to Democracy. I favour the conceptualization that takes 1975 - the year of Franco's death - as its beginning, and 1982 - the arrival of the Socialist Party (PSOE) to power with absolute majority - as its end. early 1990s scenario and the kind of behaviours that define their engagement with the social. This analysis demonstrates how films encounter an unfolding social real, codifying it in a variety of ways, becoming thus active recording devices of the prac-tices of the everyday.

$$
\text { ¿Y a qué esperas a estrenarte? ¿A las Olimpiadas esas del 92? }
$$

(Chusa in Bajarse al Moro)

\section{INTRODUCTION}

Set in the popular neighbourhood of Lavapiés, Bajarse al Moro (Colomo, 1989) deals with the day-to-day adventures of a group of mid-20s Spaniards. Chusa, the film's protagonist, goes regularly to Morocco to buy hashish and then sells it with the help of her cousin Jaimito and her boyfriend Alberto, a rather unorthodox policeman. When Elena, a petit bourgeois running away from the constraints of her family life, seeks refuge in Chusa's apartment, the idiosyncratic family unit at work in the beginning of the film turns upside down. Finding out that Elena is still a virgin, Chusa lets her 'borrow' her lover to initiate her sexual life, catalysing Alberto and Elena's affair. When Chusa finds out about Elena's virginity, she asks her: '¿Y a qué esperas a estrenarte? ¿A las Olimpiadas esas del 92?'/'What are you waiting for? Those 92 Olympics?'. This colloquial exchange between two females with radically different sexual lives provides an insight into the film's approach to late 1980s Spanish history as well as an entry point into understanding the dynamic relationship between cinematic fiction and social life.

Historians and social scientists establish 1992 as a fundamental landmark in the history of contemporary Spain. It was the year of the Seville World Exhibit, the Barcelona Olympics, the signing of the Maastricht treaty - a key step into the full realization of the EU a year later - and the celebration of Madrid as European cultural capital. By then, Spain had left behind the $c$

I specifically concentrate on films set in Madrid due to the fact that it was one of the major stages of the democratization of Spain during the Transition to Democracy and the subsequent evolution of Spanish society throughout the early 1990s. ${ }^{1}$ During Francoism, the Spanish capital was the main ideolog-ical stronghold of the dictatorship. Between the late 1970s and late 1980s, the city turned into a fundamental space for the development of new sensibilities and subjectivities. Madrid's inhabitants became active participants in a rapidly changing urban environment that attempted to cut all ties to its Francoist past 
and establish a democratic regime (Stapell 2010: 39). ${ }^{2}$ Within this historical context, cinema turns extensively towards the relationship between subject and urban space as a key representational strategy to render the unprecedented transformations in Spanish society, more generally, and Madrid, more specifically.

This analysis demonstrates how fictional films address everyday social life: first, through the use of specific dramatic structures and aesthetic approaches; and second, functioning as social agents inasmuch as they contribute to shap-ing the specific structures of the unfolding social reality they encounter. The films under study here codify everyday life in a variety of ways, becoming thus active recording devices of the practices of the everyday - that is, the recurrent forms of interaction through which individuals operate within a particular social structure.

\section{AIMING AT A NEW SOCIAL REALITY}

In The Time-Image Gilles Deleuze remarks that Italian neorealist filmmakers privileged a visual aesthetics relying on the long take and on deep focus in order to capture everyday reality. Encountering the shifting real of post-World War II Italy, they explored new aesthetic forms to portray the changing social content of a new reality that was 'no longer represented or reproduced but "aimed at". Instead of representing an already deciphered universe, Neorealism aimed at an always ambiguous, to be deciphered, real' (Deleuze 1989: 1). Film-making became a means to record social life without relying on formulaic, pre-established representational templates. As a conse-quence, out of this non-negotiable commitment to the real, the old 'action image' model of sensory-motor situations was substituted for the creation of optical and sound situations. In this type of cinema, objects and settings no longer had a strictly functional character determined by the demands of a pre-established situation. They took on

an autonomous, material reality which gives them importance in themselves. It is therefore essential that not only the viewer but the protagonists invest the settings and objects with their gaze, that they see and hear things and the people, in order for action or passion to be born, erupting in a pre-existing daily life.

(Deleuze 1989: 4)

Spanish films of the early democratic period share with their neorealist counterparts the commitment to a shifting reality and the search for aesthetic and ideological forms through which to express it. Operating within a variety of generic codes and aesthetic approaches, these films takeover the streets of Madrid, functioning as chroniclers of a society that was undergoing unprecedented economic, social and cultural change, and that, most importantly, was yet to be deciphered. Spanish society fast-forwarded through modernization, plunging into the full acceptance of market economy and novel forms of socialization, becoming part of the transnational flows of late capitalist societies. Several commentators have argued that Spain entered postmodernity without undergoing a true modernizing process in a sudden, intense fashion (Richards 2000: 46; Moreiras Menor 2000: 141; Montero 1995: 315). Negotiating the abrupt arrival of fast-paced modernization and diving into the socalled society of spectacle, Spanish youth were at the forefront in making sense of the varying rules of social exchange.
2. For a thorough discussion of the cultural and social

changes in Madrid during the

Transition to

Democracy see

Hamilton Stapell's excellent book, Remaking Madrid: Culture, Politics and Identity (2010). 
3. Bakhtin does not discuss films; he analyses 'utterances' and 'words'. I am adapting his theories into the cinematic field.

4. Rock-Ola is also one of the main settings of Pedro Almodóvar's Labyrinth of Passion (1982), perhaps the film that most directly depicts the art and music scene of La Movida in early 1980 s Madrid.
The films analysed here record the nuances of social life, the details of the everyday that cinematic representation encounters as it unfolds. They thus constitute a cinema of 'foregrounds', of specific narrative, aesthetic and ideological choices, but also a cinema of 'backgrounds', of a set of multi-layered signifiers that signal the constitutive elements of Spanish society, inserted within specific fictional narratives. In other terms, this is a cinema that aimed at capturing the evolving patterns of Spanish society and that encountered, in Bakhtinian terms, the 'utterances' of the real from which it emanated, offering therefore a representation of this time period beyond the specific agenda of each film-maker. For films 'bring with them the contexts where they have

lived' (Bakhtin 1981: 293). ${ }^{3}$ What is more, they register and mould them, through the techniques and conventions of cinematic representation (HughesWarrington 2007: 187), giving us access to the past. Consequently, they are not neutral, transparent windows on the past but ideologically and aesthetically codified interventions (Rosen 2001: 349). In this sense, our knowledge of the past stems from a series of processes of narrative comprehension where historical truth and fiction interact with one another (Ricoeur 2005: 166-67). Accepting the inseparability of history and its fictional narrations turns into a necessary step to fully comprehend how cultural artefacts codify the past.

\section{'HANGING OUT': GAME ARCADES, THE GHETTOIZATION OF THE WORKING CLASS AND THE MADRID CITYSCAPE}

iiiA Tope!!! (Fernández, 1984) is a high-school comedy structured around a series of teenage love and sex situations that feature live performances of key bands of the Spanish pop-rock scene of the 1980s - Alaska y Dinarama, Nacha Pop, Golpes Bajos, Aviador Dro, Loquillo y los Trogloditas, Gabinete Caligari, among others. Capitalizing on the marketable visibility of 'La Movida', the film was an attempt to launch the career of a new band - Objetivo Birmania. Its structure is simple: the protagonists go to high school during the day and meet

at 'Rock-Ola' - one of the most important 'La Movida' venues - at night. ${ }^{4}$ Typically, scenes begin with the group of teenagers attending a live performance. The film alternates between shots of the featured band and the teenagers' mesmerized faces. Soon, a music video aesthetic takes over: the music from the live performance continues playing in the background while the image track shows the young protagonists navigating Madrid in motorcycles and cars, laughing and having fun.

The film anchors the youth's representation in the specific coordinates of 1980s Madrid. However, the comedy-of-situations mode of address seems little else than a narrative alibi for the unparalleled succession of cutting-edge musical performances. For iiiA Tope!!! plays a series of 'stock' situations the male protagonist's attempts to have sex with a hot blond, the teenagers' 'occupation' of adult houses to have sex, the dream to make it into the music world - to ultimately offer a 'clean' portrayal of common leisure practices among Spanish youth of the 1980s. It is thus a film about teenagers 'hanging out' that remains on the surface of the cultural Zeitgeist it exploits, vacuuming out the nuances of the social fabric it portrays. Nonetheless, it does provide a series of insights into young people's social roles during this period. All the teenagers live with their parents or older relatives and have no independence when confined within the family household, unless it is vacant. Going out to bars or clubs, being in tune with the latest music tendencies and having sex become tools towards achieving social agency. Rather than an underground 
movement, the film depicts 'La Movida' as a mainstream cultural trend that, by the mid-1980s, has turned into an essential component of the day-to-day practices of the period's youth. Within the comfortable and 'light' middleclass universe of iiiA Tope!!!, the excessive consumption of alcohol or the recreational use of drugs is absent. Unemployment, social marginalization and delinquency - three common problems among youth during this period are totally invisible.

Colegas (De la Iglesia, 1982) is the flip side of the coin of iiiA Tope!!!. Far from situating the story in a safe 'leisurely limbo', it anchors the lives of its characters in the specific socio-economic characteristics of Madrid. It deals with three youths in their late teens - Rosario, Antonio and José - trying to get money for Rosario so that she can have an illegal abortion. ${ }^{5}$ The film is set in Barrio de la Concepción, a peripheral working-class neighbourhood situ-ated

beyond the M-30 - a motorway that circles around central Madrid. ${ }^{6}$

By the mid-1970s, due to real estate speculation and deficient urban planning, Madrid had become an overgrown space. This caused 'social segregation between the center and the periphery ... the expulsion of the popular classes from the center of the city and the increased degradation of the environment' (Stapell 2010: 23). Thus, Madrid's spatial layout reflected the economic imbalance at the core of its societal structure: the working and lower classes inhabited the periphery, suffering the consequences of the economic crisis the country experienced from late Francoism until the late 1980s (López and Rodríguez 2011). ${ }^{7}$ The film repeatedly highlights the 'forced idleness' of the protagonists due to the impossibility of finding a job. They are the noncultivated, uneducated young substratum of a society that excludes them from the evolution towards 'progress'. ${ }^{8}$ Trapped within this scenario, their lack of access to money triggers their fall into delinquency.

Colegas focuses on a repressed social problem of euphoric accounts of early Spanish democracy - the marginalization of the working classes from the national modernization project - spatializing their social ghettoization within the urban design of Madrid. Consequently, it establishes a clear link between geographic and economic social marginality. The M-30 highway is the fron-tier, the wall that separates the working classes from a city that has physically expelled the working classes outside its limits (Melero 2013: 74). The recurrent visualization of the overwhelming architecture of Barrio de la Concepción beehive buildings turns into a means of 'ideological interpellation' (Balibrea 2001: 188) that calibrates the social agency of the young characters against an overpowering social and economic reality. The film frames the characters against the gigantic housing structures that surround them and constitute the limits of their physical and class mobility. The famous Pirulí (Torrespaña tower) - an unequivocal sign of the modernization and global connectivity granted by telecommunication technologies - is a distant landmark in the background, as the two friends look for a job, walking around their neighbourhood. In other terms, Colegas' spatial cartography features a common characteristic of major cities - that is, 'a geography of centers and margins that not only strengthens existing inequalities but sets in motion a whole series of new dynamics of inequality' (Sassen 2000: 85). In addition, the film constantly foregrounds the mobility facilitated by the transportation infrastructures that surround the working-class neighbourhood - epitomized by the M-30 motor-way - in contrast with the ghettoization of the working-class youth. Their spatial marginality supersedes the promise of mobility modern transportation technologies offer. The friends only abandon their neighbourhood, using the
5. Abortion did not become legal in Spain until 1983.

6. Pedro Almodóvar's depiction of urban alienation among the working classes, ¿Qué he hecho yo para merecer esto!! (1984), is also set in Barrio de la Concepción. The overwhelming monstrosity of the beehive buildings plays a key role in defining the relationship between human subjects and cityscape.

7. López and Rodríguez argue that the 1973 recessionary crisis was more severe in Spain than in other

European countries for one main reason: the failure to change the country's economic model, maintaining its dependence on tourism and the construction sector. Even after the advent of democracy, the successive democratic governments did not change this economic model, including the PSOE, which ruled Spain from 1982 to 1996.

8. As Mark Allinson observes, 'the education of many young people up to university level created an expectation of similar access to appropriate employment which the 1980s and 1990s have spectacularly failed to deliver' (2001: 267). 
9. In the 1980s personal computers and video consoles were not common yet.

10. In Deprisa, deprisa, every time Carlos and his friends commit a crime, they burn their getaway car in an empty field. His mate Meca enjoys this spectacle of destruction as though he were in a trance. For Pablo, Meca and their peers establish a continuum between the simulated violence they enjoy at the arcade and the acts of violence they perform. transportation technologies that cartographically situate them in the outskirts of Madrid, when they attempt to 'cross over' to other social and economic strata to earn money - the gay sauna where they ultimately fail to sell their services; Atocha station, from which Antonio and José depart to Morocco serving as hashish moles; or the large apartment where the illegal abortion clinic is set up. Their failures to obtain money eventually bring the inevitability of violence to the fore. The film establishes a symbolic continuity between the youths' leisurely activities and the alluring power of violence.

Colegas' depiction of the early 1980s Madrid's youth pays special attention to leisurely activities occurring within shared, public spaces. It starts off with a series of video game screens, signalling the importance of 'los recreativos'/'game arcades' as a gathering centre for the youth. ${ }^{9}$ All the featured games have to do with speed - chase simulators - or representational violence - shoot and destroy. The last video screen image is the word 'Fin', anticipating the fact that the story the spectator is about to see has already been written, signalling thus the 'social determinism' that ultimately defines the ideological discourse of the film (Trashorras 1998: 99-100). As opposed to the corner bar - the gathering hub for older generations - the game arcade was at this historical juncture one of the fundamental spaces where young people congregated to spend their time. As Gonzalo Goicoechea, the film's co-writer, states,

Esos locales recreativos eran un punto de encuentro para la gente como la que sacamos en Colegas, y los videojuegos eran una excusa para reunirse y hacer pandillas, ligar, follar, tomar drogas duras y blandas. Además, los videojuegos eran tremendamente violentos y creaban en los jóvenes mucha ansiedad. Por no hablar de que se trataba de algo hiperadictivo/the game arcades were a meeting point for the kind of people we feature in Colegas, and the videogames were the alibi to meet, flirt, fuck, take hard and soft drugs. Besides, these video games were tremendously violent and they created a lot of anxiety. Also, they were very addictive.

(Melero 2013: 73)

It is thus not accidental that Pablo, the main protagonist of Deprisa, deprisa (Saura, 1981), is also shown at a game arcade playing a violent game. In this case, Saura superimposes the game screen with Pablo's reflection, as he frantically pushes buttons to destroy enemy vessels. ${ }^{10}$ Through the depiction of the game arcades as a key signifying space for the younger generations, both films highlight the importance of the transitory, shared, spaces city inhabitants use in their everyday to define the specificity of the urban (Delgado 1999: 45). Like Colegas, Deprisa, deprisa establishes a clear link between the main characters' delinquency and their spatial ghettoization within peripheral Madrid: unsurprisingly, these characters hardly leave their neighbourhood. When they do - to visit, for example, a historical landmark such as 'El Cerro de los Ángeles' - the police check their documentation, suspecting they are up to some kind of wrongdoing given their incongruous presence in this location. Unlike the case of Colegas, this film does not offer a moral alibi for the characters' delinquency. Nonetheless, it does establish a rather unambig-uous correlation between urban spatiality and delinquent social behaviour. As workingclass young men and women in early 1980s Spain, the characters of Deprisa, deprisa have no option but to become delinquents in order to earn 
money. Ultimately though, their hold-ups turn into increasingly difficult adrenaline-fuelled actions that become addictive, like the video games at the arcades they constantly play. In the end, the same economic and social order that excludes them from agency castigates their delinquency. Their only alternative is to escape the social order that oppresses their kind and, one way or another, purges it. Only Ángela manages to prevail, leaving the neighbourhood, escaping thus the condemnation that awaits her if she remains stuck within the spatial logic of 1980s Madrid.

While Deprisa, deprisa deals with the localized young delinquency of 1980 s youth in marginal Madrid, Colegas goes a step further, addressing the transnational dimension of the working class' economic exploitation. Rogelio, the drug dealer who had used Antonio and José to get drugs in Morocco and who also serves as the intermediary with an international network of baby trafficking, is the link between the localized social reality of peripheral Madrid and the progressive incorporation of Spanish society into the networks of transnational capitalism. It is thus not accidental that Rosario's baby will go to 'a foreign family that will treat him well'. After the friends back out from their deal, Rogelio decides to kill them. Once Antonio realizes he wants to locate his sister and José to harm them, he refuses to cooperate with Rogelio and his henchmen. When Antonio tries to run away, the chase takes place near a series of recently constructed, modern buildings. Eventually, one of Rogelio's henchmen shoots and kills Antonio in a construction site, precisely where this new modern Spain is being erected. The film deploys a long establishing shot to frame the imposing massiveness of modern buildings in contrast with the fragility of the character's life. In other words, the rapid modernization of democratic Spain was carried out at the expense of those - like the young inhabitants of Barrio de la Concepción - who were excluded from the possibility of social mobility and figuratively buried underneath the emblems of an evolving country.

This is precisely the starting point of Historias del Kronen (Armendáriz, 1994): an overgrown, post-Transition 1990s megalopolis that swallows its inhabitants. The film starts with a slow panoramic shot that defines the sheer enormity of Madrid. It is an expansive urban space defined by the indelible presence of modern architecture. It is worth noting that films such as El crack dos (Garci, 1983) had anticipated in the early 1980s this transformation of the urban landscape through the repetitive foregrounding of cranes in juxtaposition with the fleeting old Madrid cityscape. The soundtrack of the film immediately qualifies the contemplative mood that the image offers. As the camera slowly pans to encompass the sprawling dimensions of overgrown Madrid, a series of gradually louder sounds - ambulance sirens, constant traffic, construction drills, a taxi dispatch - overwhelm the spectator's ears. We are inside a sonically saturated urban jungle that deluges our senses. The film soon turns this abstract urban nightmare into a chronicle of the pleasure and excess-driven life of a group of upper-middle-class youngsters in the Post-Olympic era, a time where the collective project of integrating Spain within Europe and modernizing the country is no longer at its peak. Instead, it is a society characterized by 'absence, negativity, and the lack of a Utopian outlook' (Moreiras Menor 2000: 35).

Based on an eponymous novel of José Ángel Mañas, Historias del Kronen follows the night-to-night leisurely activities of Carlos, a 'tomorrow-doesn'texist' young man who seeks pleasure in the excessive consumption of drugs and alcohol, and a variety of sexual encounters with several female partners. He lives in his parents' comfortable upper-middle-class apartment in the outskirts 


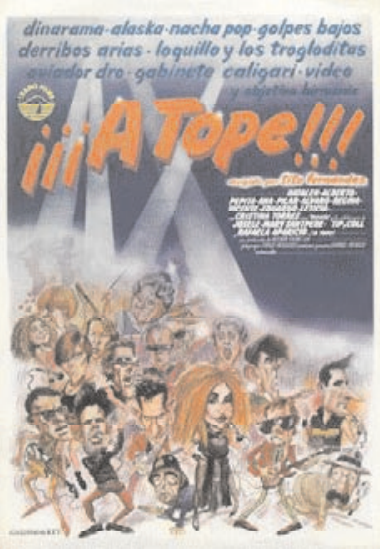

Figure 1: iiiA Tope!!! was designed to capitalize on the commercial appeal of

Spanish pop-rock bands of

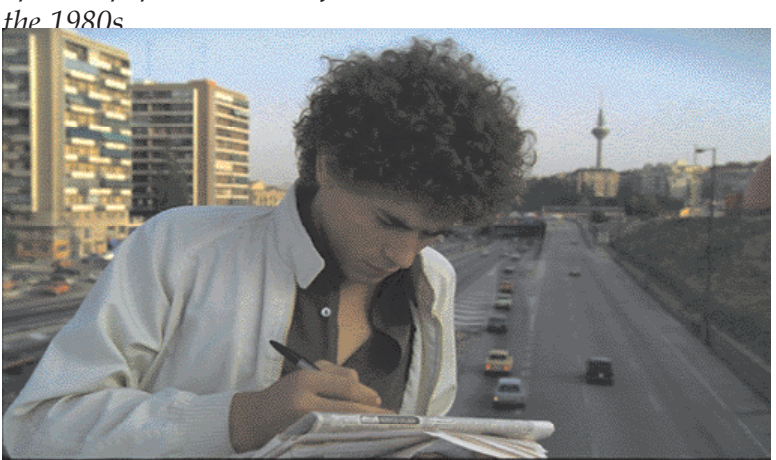

Figure 3: José looks for a job in his neighbourhood with the 'Piruli' in the background.

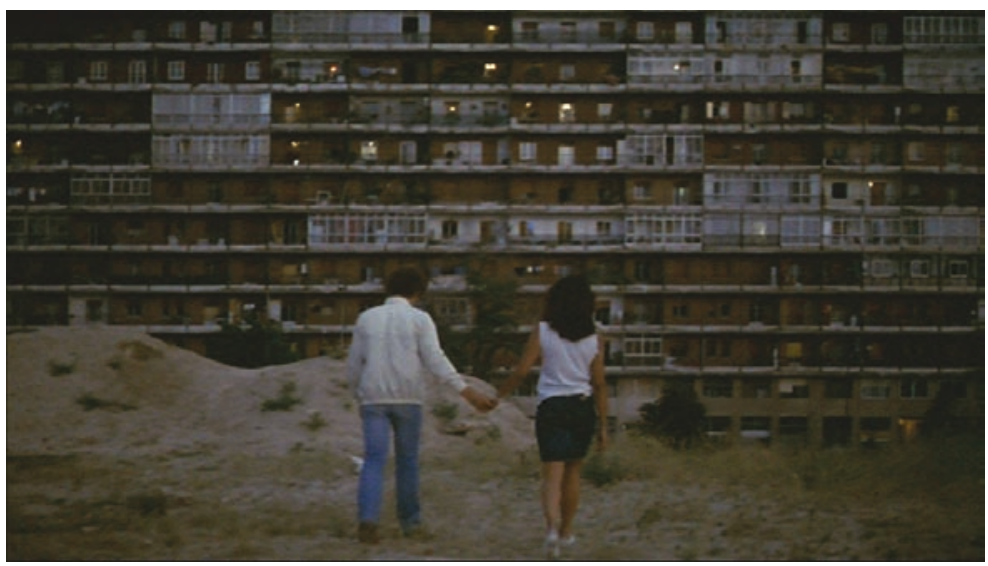

Figure 2: The monstrosity of the beehive buildings frames the existence of Colegas' characters.

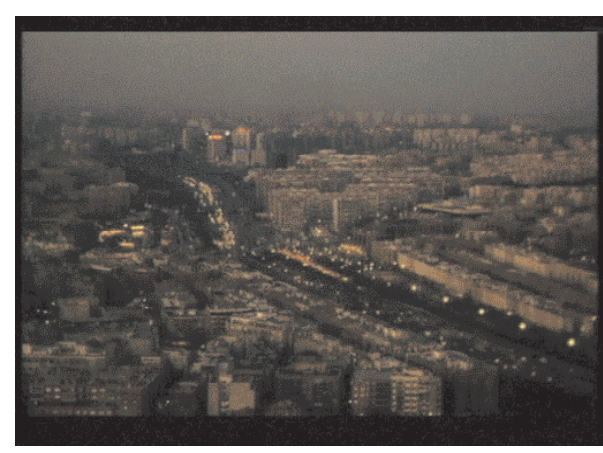

Figure 4: Opening shot of Historias del Kronen.

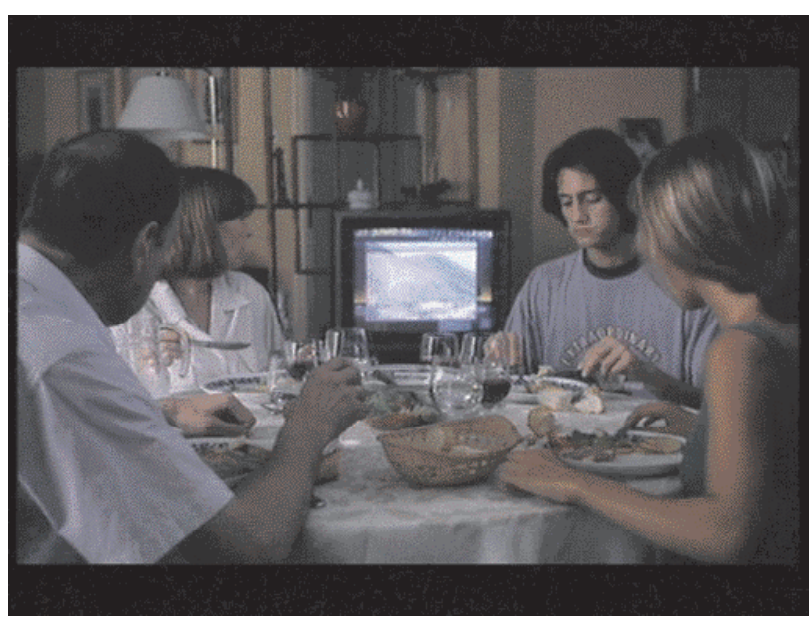

Figure 5: The TV screen presides over every family meal in Historias del Kronen. 

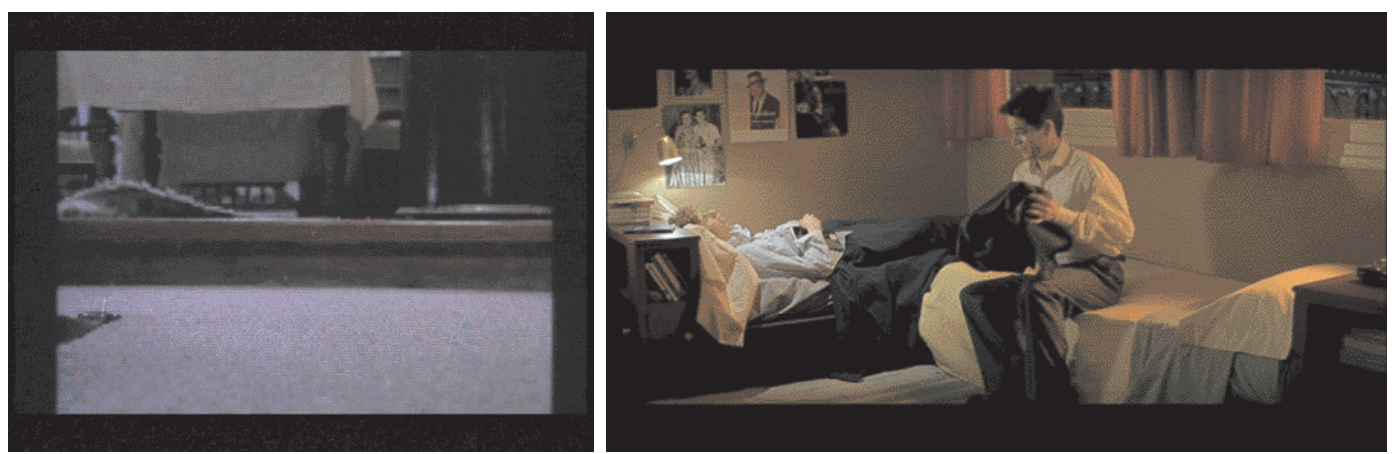

Figure 6: The video camera keeps rolling Figure 7: The two brothers share a warm-coloured room when the characters leave Pedro's house in in Los peores años de nuestra vida. Historias del Kronen.

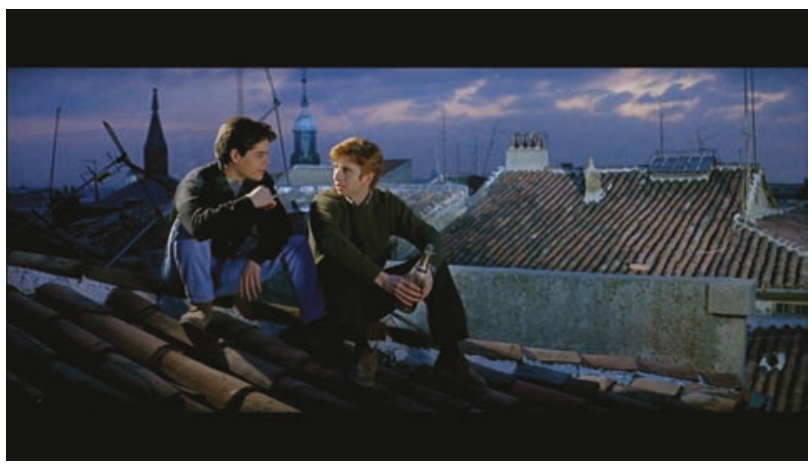

Figure 8: The Madrid downtown rooftops in Los peores años mentira. de nuestra vida.

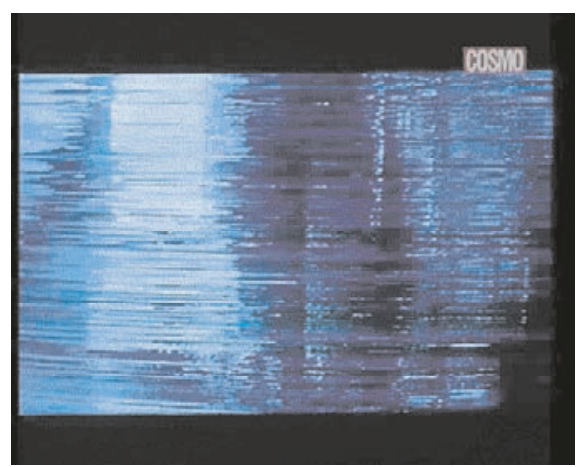

Figure 9: Codified porn in Todo es 
11. In 1977, there were eight million TV sets in Spain; only 10 per cent were colour TVs (Palacio 2012: 9). By the beginning of the 1980s, most Spanish households had colour TV sets.

12. Antonio and Rosario's family owns a colour TV set. Nonetheless, it is only featured once in the whole film, as a clever narrative device to make Rosario realize, through the broadcasting of a commercial, that she is late with her period and she may be pregnant. and has access to motor vehicles to move around the downtown locales he frequents. Carlos and his friends bend social rules: driving in the opposite direction, kamikaze style; breaking into construction sites to play tightrope walker and engage in quick sex; and hanging from bridges over incoming traffic. Immersed in the post-ideological scenario of Historias del Kronen, young people turn towards sensorial satisfaction and a commitment to acceleration and immediacy to cope with the burden of social living. The film is thus structured around the continuous failure to takeover space and the lack of harmony between two bodies: the city itself and its inhabitants (Smith 2006: 83). As opposed to the specificity of the spatial localization of Colegas and Deprisa, deprisa, Historias del Kronen makes a more encompassing diagnosis. As anticipated by the sonic saturation of the opening sequence, urban alienation is everywhere, a condition intrinsic to the streets, highways and buildings of a modern, internationally connected city such as Madrid. In this context, the growing prevalence of audiovisual technologies within the everyday practices of youth becomes a privileged arena in which the shifting social order is codified within Madrid's cityscape.

\section{FROM COLOUR TV TO SNUFF MOVIES: VIOLENCE AND AUDIO-VISUAL CONSUMPTION}

In Historias del Kronen, television and digital recording and viewing devices turn into symbolic characters of utmost importance, highlighting a shift in habits and, consequently, a transformation in relevant aspects of contemporary social life (Brändle Señán 2007: 77). The constant presence of the televisual and videographic images in the film points to the growing importance of this type of consumption within the early 1990s milieu. This consumption pattern had started in the late 1970s and early 1980s with the increasing penetration of the TV set within Spanish households.

After performing one of his robberies in Deprisa, deprisa, Pablo goes to visit his grandmother. He has a present for her: a colour TV. The old lady, who lives in a modest shack, is ecstatic. She has fulfilled a life dream. In the second half of the 1970s, television became the most significant audio-visual industry in Spain, surpassing the social importance of cinema, the radio or the written press, entering most households (Palacio Arranz 2006: 316-17). By the 1980s, the purchase of colour televisions had become widespread, becoming not only a symbol of the country's democratization - as opposed to the black and white broadcasts associated with the Francoist regime - but also an unequivo-cal signal of the ascent of sectors of the working class to the 'middle class'. ${ }^{11}$ In this sense, it is particularly significant that when Colegas shows José's family having dinner, there is no television set in the living room - they do not own one since they are too poor. ${ }^{12}$

By early 1990 - as screened in Historias del Kronen - colour TV sets are not only present in every Spanish household but are also ubiquitous domes-tic appliances. Their soft glow illuminates almost every family interaction. Every time Carlos' family gathers to eat, the TV occupies the centre of the frame, a witness of a decomposing social order. Furthermore, the TV set acts as a mesmerizing vanishing point where Carlos' parents and sister invariably focus their gaze, unable to escape its alluring power. The television thus func-tions as an omnipresent character 'clearly interfering with communication: a brash and jarring challenge to the putative security of an older Spain, centered around the paternal Catholic family' (Fouz-Hernández 2000: 86). In addi-tion, it constantly spits out news about political corruption, calling attention 
to the rampant ethical crisis at the core of Spanish society during the last Felipe González PSOE mandate and the succession of scandals that ultimately brought an end to his tenure. The television screen historically contextualizes the social coordinates through which Carlos and his peers operate: the disenchantment following the internationalization of Spain in 1992 and the rampant corruption among the political and economic elites that had dictated the transition from dictatorship to democracy.

The film also lends great significance to the emergence of home videorecording equipment within the leisurely activities of Spanish youth. Carlos and other friends go to Pedro's house to celebrate his birthday. Pedro welcomes them with a video camera. From then on, the narrative alternates between the digital and the cinematic image. Roberto and Carlos decide to force Roberto to drink whiskey to celebrate his anniversary even though this may jeopard-ize his life since he is a diabetic. As soon as he consumes enough alcohol, he becomes unconscious. Eventually, he dies. Once Carlos and Roberto start to force-feed Pedro the alcohol, the digital video image takes over the narra-tive; its materiality turns into the codifying device through which the night is recorded. As the young men leave Pedro's house to take him to the hospital, the camera is left on the ground, still running, capturing an empty frame as though it had suddenly acquired an autonomous character. Even though the film ultimately takes spectators to the hospital to certify Pedro's death, aban-doning the digital mode of address it had momentarily adopted, this aesthetic choice points to the increasing utilization of video recording among Spanish youth in the mid-1990s, anticipating its pervasive presence in the social field a few years later, when digital technology would become a fundamental tool of social and cultural exchange. Adopting the materiality of the videographic image as a storytelling device, Historias del Kronen exhibits a commitment to the real, in Deleuze's terms, in an effort to actively engage with the very characteristics of the social it attempts to capture.

In addition, after Roberto and Carlos return home, they sit down in front of the TV watching the recording of Pedro's death. Throughout the rest of the film, their fascination with violent imagery had been already highlighted through their repeated viewing of Henry: Portrait of a Serial Killer (McNaughton, 1986) and their attraction to the alleged existence of snuff movies - hardcore

violent films in which people die for real. ${ }^{13}$ Watching the recording of Pedro's death, they are viewing what they coveted: a snuff film. In this case, they are both spectators and video-makers, since they recorded their friend's death. In other terms, the very technology that defines the leisurely coordinates of mid-1990s Madrid youth has turned into one of the devices to codify the grow-ing anxiety of young people as they negotiate the urban space they inhabit. The commitment to the representation of social reality that characterizes films such as Historias del Kronen was not, by any means, the only template at work within Spanish cinema of this period. The comedic turned, in fact, towards an aesthetic of timelessness to address (or fail to address) the social and cultural coordinates of 1990s Spain.

\section{COMEDIA MADRILEÑA REDUX: TIMELESSNESS, ROOFTOPS AND CODIFIED PORN}

In the early 1990s, a series of films updated the 1980s comedia madrileña into the contemporary milieu. Two works are especially remarkable in this respect: Los peores años de nuestra vida (Lázaro, 1994) and Todo es mentira (Armero,
13. A year after Historias del Kronen, Alejandro Amenábar made Tesis (1995), a snuffcentred horror thriller that deals with the overwhelming presence of violent imagery in the Spanish mediascape.

Amenábar's film utilizes the imperfect imagery of digital technology - snuff video - to diagnose the ethical dimension of this type of consumption and its effects on the spectator's sensorium in 1990s Spanish society (Rodríguez Ortega 2005). In fact, several other films of this time period most remarkably Kika (Almodóvar, 1993) and El dia de la bestia (Iglesia, 1995) - chronicle the key role of audiovisual technologies in the construction of identity and the ubiquity of violence imagery within the Spanish public sphere. Like in Historias del Kronen, the youth is at the forefront of this cultural turn, codifying their daily habits through recurrent digitization - that is, their transformation into audio-visual artefacts where the real is mediated through the materiality of the digital. 
1994). Contemporary reviews make this link explicit, unfavourably comparing them to the 1980s comedies (Bonet Mojica 1994: 48; Torreiro 1994: 28). Other commentators identify Todo es mentira as the Ópera Prima (Trueba, 1980) for the 'X generation' (Montero 1994: 94). Unlike Historias del Kronen, or the cycle of Madrid-based romantic comedies of the 1980s - a group of films that depict modes of socialization that came into existence during the transition (Monterde 1993: 127-28) - these films adopt one of two postures. They either attempt to vacuum out the specificities of the particular historical juncture from which they spring, rendering a timeless depiction of romance - Los peores años de nuestra vida (Casas 1994: 52) - or they deal with the dangers of heterosexual conformity without explicitly reflecting on the constitutive nuances of the 1990 s social fabric - Todo es Mentira. Nonetheless, even if tacitly, they offer insights into the social behaviours and problems of Spanish youth.

Los peores años de nuestra vida focuses on a love triangle between two brothers, Alberto and Roberto, and a young art student, María. Alberto is an aspiring writer, part-time musician, fake English teacher and stand-up comedian who embodies the essence of romanticism. Roberto works in a bank and is pragmatically successful with women, unlike his brother. Alberto starts dating María, who, attracted by his humourous and honest nature, wants to forget a depressing affair with an egotistical married man. Eventually, she realizes she loves his brother Roberto. Up until the last moment of the film, Alberto insists that he and María are going to travel to Paris together and, once in the station, he instead commands his brother to join her in a final twist. For him, this is the most romantic thing to do. Faithful to his idealism, he 'hands over' the woman he loves to his brother.

Along with the warm red-and-orange colour palette that pervades the film, the recurrent visualization of the picturesqueness of Madrid's rooftops is the key mechanism through which Los peores años de nuestra vida renders a timeless, romance-driven, comedic intervention that could have taken place in any old European city. Nonetheless, as in Historias del Kronen or Colegas, the film situates its youth inside the parental household, offering an understanding of one of the dominant forms of socialization in early 1990s Spain.

Despite the fact that Roberto works in a bank and, like Alberto, is already a man in his twenties, he shares a room with his brother. They both live with their parents. Los peores años de nuestra vida does not even address the possibility of emancipation. In this regard, it is worth mentioning that during the 1980 s and early 1990s real estate prices soared in an unprecedented fashion. Additionally, the job market for the youth became increasingly difficult. This entailed that many young people opted to stay at their parents' homes. By 1997 only 20.5 per cent of men and 30 per cent of women between 16 and 34 had left the family household (Requena 2002: 10). Moreover, the average age of emancipation rose from 28 in the late 1980 s to over 30 in the mid-1990s. It is not surprising that Alberto and Roberto share a room in their parents' home, where they probably grew up together, in a relatively small downtown family apartment in quaint Madrid. These data point to an unequivocal sociological reality: the difficulty for youth in achieving the economic dependence sufficient to move away from the parental home. In other words, the teenagers from iiiA Tope!!!, ten years later, would still live with their parents.

Despite the fact that they are radically different works, Todo es Mentira and Historias del Kronen have been labelled 'Generation- $X$ ' films (Caparrós Lera 
2005: 22). In his analysis of the latter, Fouz-Hernández (2000) has convincingly argued that this term is at least questionable without taking into consideration historical and cultural specificities. Thus, it may be more adequate to forget this kind of transterritorial label and analyse Todo es mentira as a depiction of the fear of responsibility and commitment among the mid-20s Spanish youth of the 1990s.

The film deals with several heterosexual couples that face an affective crisis but mostly focuses on Pablo and Lucía. Pablo, a self-labelled 'unfocused individual', who does not seem to have any occupation, is allured by Lucía's beauty and easily allows her to move in with him. From then on, the narrative revolves around Pablo's growing anxiety in regard to Lucía's impact on his life. Her obsessive cleaning and compulsive reorganizing of his messy apartment proves to him that he has lost his coveted freedom. As a reaction to this threat, he constantly expresses his need to escape to 'Cuenca' - a town in Castille that functions as a metaphor for a way-out of the impending arrival of a maturity he does not want to confront. Ultimately he will fail in this endeavour. As Ariel, a friend of Pablo's who deals with a similar issue, states, 'Si no presto atención, terminaré rodeado de niños llorando y haciéndome socio del Real Madrid'/'If I don't pay attention, I will end up surrounded by screaming children, becoming a Real Madrid ticket holder'.

Set mostly in Lavapiés, the film establishes an explicit link with the 1980s romantic comedy through the character of 'La Sucia/The Dirty One' - a woman who stands in the corner of Pablo's house and repeatedly asks him to fill out a questionnaire. ${ }^{14}$ 'La Sucia' - an alternative-looking woman iden-tified with this nickname because she always wears the same blouse - turns into a sexual, hippie fantasy for Pablo and his friends. Having sentimental problems with Lucía, Pablo sleeps with 'La Sucia'. After having sex, Pablo confesses to his new lover that he feels bad after cheating on his girlfriend. 'La Sucia', surprised, replies '¿Por un polvo?'/'For a fuck?'. The hippie woman has become a momentary 'sexual release' for the ultimately conservative and lost young male who cannot cope with the threat of female agency. For, in Todo es mentira, masculinity seems in crisis, indeed. Watching porn films turns into a symbol of this 'in-crisis' male subjectivity and a sociological diagnosis of media consumption during this era.

In a scene where Ariel and Pablo discuss their respective sentimental burdens, they sit in front of the TV, watching a pornographic film filtered through a Canal+ codified signal. Given that it was the only pay channel, Canal+ tried to offer content that other networks did not have. It acquired the rights of football and boxing broadcasts and also started showing pornographic films. Every Friday night, the private channel broadcast a porn film. Since most of the population did not buy the Canal+ service, viewing the 'codified porn film' Friday event became a widespread practice among signifi-

cant sectors of the population, garnering a cult following. ${ }^{15}$ Framing a discussion between two males about the dangers of heterosexual commitment with the visualization of the codified Canal+ porn film, Todo es mentira incorporates a common form of socialization at the time of its making into the fictional world of the film. Once again, the fictional and the real interact, inseparably, to offer a diagnosis of common practices of social life during this time period. Like in Historias del Kronen, the TV set, specifically, and audio-visual consumption, more generally, is at the centre of young people's negotiation of the daily coordinates of urban life.
14. The most obvious link with the 1980s comedia madrileña is Ópera prima. Whereas in the latter, the hippie lifestyle of Violeta offers Matías a refuge from a social reality that alienates him, and ultimately,

a heterosexual partnership, in the 1990s, the hippie 'La Sucia' is only a onenight stand.

15. The short documentary 'Mundo X-Porno codificado' explains the importance of the Canal+ porn film Friday broadcast: http://www. plus.es/ video/Mundo-XPornocodificado/ 20090 901pluutmmux_4Ves/. 


\section{CONCLUSION}

In a thought-provoking essay, Giuliana Bruno defines film as modern cartography. She goes on to state that cinema 'is a mobile map - a map of differences, a production of socio-sexual fragments and cross-cultural travel. A voyage of identities in transito, and a complex tour of identifications, film's siteseeing is an actual means of exploration' (1997: 23). The Spanish films analysed here offer a series of insights into the social behaviours of youth within Madrid's cityscape of the 1980s and early 1990s, cartographically defining the shifting character of the dynamic relationship between city and urban dwellers. In this sense, it is important to understand how these films may capture the specificities of certain forms of socialization and particular cultural practices. At the same time, it is necessary to remark that these 'utterances' are perpetually changing since the processes of urbanization that define them are in constant flux, or in transito, in Bruno's terms.

Films such as Colegas and Deprisa, deprisa politically engage with the urban overgrowth of the Madrid cityscape as a means to denounce the marginalization of the working classes and the spatial reflection of such discrimination within the urban layout of the city during the early days of democracy in Spain. What is more, they situate the very logic of capitalism at the centre of this spatial ghettoization of the unprivileged since 'residential differentiation is produced, in its broad lineaments at least, by forces emanating from the capitalist production process, and it is not to be construed as the product of the autonomously and spontaneously arising preferences of people' (Harvey 1985: 123). In short, economic and cartographic marginalizations are parts of the same processes.

Historias del Kronen depicts the affective and intellectual malaise among the youth in the 1990s post-ideological social fabric while chronicling the growing importance of audio-visual technologies within the cultural and social landscape of this period. iiiA Tope!!!, Los peores años de nuestra vida and Todo es mentira, for their part, focus on the everyday life of youth while often failing to address the political nuances of the time period they address. Nonetheless, even if indirectly, they offer significant visions of some of the defining charac-teristics of Spanish society - the emergence of new cultural phenomena (La Movida), the non-emancipation from the parental home or the attempt to delay adulthood's responsibilities by seeking refuge in a series of leisure practices.

In broader terms, in the 1990s post-ideological world, Spanish film scrutinizes how the consumption of (often violent and sex-driven) audiovisual artefacts decisively mediates social interactions among youth. This is perhaps what separates 1980s and early 1990s Spanish cinema: the attempt to represent the exact coordinates of social struggle through the utilization of mise-en-scène versus the consumption of digitally codified porn images and the corrupted faces of politicians on the TV screen within a social order that has fully accepted the skewed logic of the 'democratic game'.

Films often interact with the social particularities of a given time period as a result of a conscious engagement with the reality from which they emanate. Other times, the unfolding and multi-layered nuances of social life enter cinema inadvertently, appearing within the limits of the frame and soundtrack of a film as a consequence of their existence within the depicted social fabric. In my view, this is precisely one of the most fruitful arenas in which to analyse how the cinema addresses the period it represents: the thorough exploration of the audio-visual components of a film beyond its dramatic structure, its most salient aesthetic characteristics and its intended ideological stance. 
To conclude, one must always remember that the urban never fully crystallizes. It is instead evolving and fluctuating, often fortuitously and randomly (Delgado 1999: 25; Donald 1992: 422). Consequently, specific cinematic interventions codify the social from the very immediacy of an always shifting reality, offering valuable, even if only partially, insights into the unpredictable everyday.

\section{ACKNOWLEDGEMENTS}

This article was written in the context of the Research Project I+D+i 'Cinema and Television in Spain during the Post-Transition' (CSO2012-31895), Ministry of Economy and Competitiveness, Spanish Government.

\section{REFERENCES}

Allinson, M. (2001), A Spanish Labyrinth: The Films of Pedro Almodóvar, London: I.B. Taurus.

Armendáriz, Montxo, (1995), Historias del Kronen, Madrid: Alert Films. Balibrea,

M. P. (2001), 'Urbanism, culture and the postindustrial city:

Challenging the "Barcelona model"', Journal of Spanish Cultural Studies, 2: 2, pp.

187-210.

Bakhtin, M. (1981), The Dialogic Imagination, Austin: University of Texas Press.

Brändle Señán, G. (2007), 'Consumo y cambio social en España: evolución en el equipamiento doméstico (1983-2005)', Reis, 120: 7, pp. 75-114.

Bruno, G. (1997), 'Site-seeing: Architecture and the moving image', Wide Angle, 19: 4, pp. 8-24.

Bonet Mojica, LI (1994), 'Woody Allen en Lavapiés', La Vanguardia, 14 August, p. 48.

Caparrós Lera, J. M. (2005), La pantalla popular, Madrid: Akal.

Casas, Q. (1994), 'El romanticismo y la realidad', El Periódico, 16 August, p. 52.

Colomo, Fernando (1989), Bajarse al moro, Madrid: Ion Films, Lola Films and TVE.

De la Iglesia, Eloy (1982), Colegas, Madrid: Ópalo Films.

Deleuze, G. (1989), Cinema 2: The Time-Image, Minneapolis, MN: University of Minnesota Press.

Delgado, M. (1999), El animal público: hacia una antropología de los espacios urbana, Barcelona: Anagrama.

Díez del Río, I. (1982), 'La Contracultura', Revista de Estudios de Juventud, 6, pp. 101-32.

Donald, J. (1992), 'Metropolis: The city as text', in R. Bocock, S. Hall and K. Thompson (eds), The Social and Cultural Forms of Modernity (Understanding

Modern Societies), Cambridge: Polity Press, pp. 417-70.

Fernández, Tito (1984), iiiA Tope!!!, Madrid: Acción Films.

Fernández Armero, Álvaro (1984). Todo es mentira, Madrid: Atrium Productions and TVE.

Fouz-Hernández, S. (2000), '¿Generación X? Spanish urban youth culture at the end of the century in Mañas's/Armendáriz's Historias del Kronen',

Romance Studies, 18: 1, pp. 83-98.

García, R. (1994), "'Todo es Mentira" se abre paso en el cine español', El País, 17 September, http://elpais.com/diario/1994/09/17/cultura/ 779752801_850215.html. Accessed 20 February 2016.

Graham, H. and Sánchez, A. (1995), 'The politics of 1992', in H. Graham and J. Labanyi (eds), Spanish Cultural Studies: An Introduction, Oxford: Oxford University Press, pp. 406-18. 
Harvey, D. (1985), The Urbanization of Capital, London: John Hopkins University Press.

Hughes-Warrington, M. (2007), History Goes to the Movies: Studying History on Film, London: Routledge.

López, I. and Rodríguez, E. (2011), 'The Spanish model', New Left Review, 69, http://www.newleftreview.org/?view=2895. Accessed 8 February 2016. Martínez

Lázaro, Emilio (1994), Los peores años de nuestra vida, Madrid:

Fernando Trueba Producciones Cinematográficas and Iberoamerican

Films Producción.

Melero, A. (2013), La noche inmensa: la palabra de Gonzalo Goicoechea, Madrid:

Grupo de Investigación 'Televisión-Cine: memoria, representación, industria' (TECMERIN).

Monterde, J. E. (1993), Viente años de cine español: un cine bajo la paradoja 19731992, Barcelona: Paidós.

Montero, M. (1994), 'Retrato de la generación X', El Periódico, no. 22, 11 September, p. 47.

Montero, R. (1995), 'Political transition and cultural democracy: Coping with the speed of change', in H. Graham and J. Labanyi (eds), Spanish Cultural Studies: An Introduction, Oxford: Oxford University Press, pp. 315-20. Moreiras Menor,

C. (2000), 'Spectacle, trauma and violence in contemporary Spain', in B. Jordan and R. Morgan-Tomasunas (eds), Contemporary Spanish Cultural Studies, London: Arnold, pp. 134-42.

Palacio Arranz, J. M. (2006), 'Cincuenta años de televisión en España', Tendencias, 6, pp. 315-21.

Palacio, M. (2012), La televisión durante la Transición española, Madrid: Cátedra.

Requena, M. (2002), 'Juventud y dependencia familiar en España', Estudios de juventud, 58: 2, pp. 1-13.

Richards, M. (2000), 'Collective memory, the nation-state and post-Franco society', in B. Jordan and R. Morgan-Tomasunas (eds), Contemporary

Spanish Cultural Studies, London: Arnold, pp. 38-47.

Ricoeur, P. (2005), Tiempo y narración: configuración del tiempo en el relato de ficción, México DF: Siglo XXI.

Rodríguez Ortega, V. (2005), 'Snuffing Hollywood: Transmedia horror in Tesis', Senses of Cinema: An Online Film Journal, 36, http://sensesofcinema. com/2005/the-metaphysics-of-violence/tesis/. Accessed 8 February 2016. Rosen, P. (2001), Change Mummified: Cinema, Historicity, Theory, Minneapolis: University of Minnesota Press.

Rueda Laffond, J. C. and Chicharro Merayo, M. M. (2004), 'La representación cinematográfica: una aproximación al análisis sociohistórico', Ámbitos,

11: 12 , pp. 427-50.

Sassen, S. (2000), 'The global city: Strategic site/new frontier, American Studies, 41: 2/3, pp. 79-95.

Saura, Carlos (1981), Deprisa, Deprisa, Madrid: Elías Querejeta Producciones Cinematográficas S.L.

Smith, P. J. (2006), Spanish Visual Culture: Cinema, Television, Internet, Manchester: Manchester University Press.

Stapell, H. M. (2010), Remaking Madrid: Culture, Politics and Identity after Franco, New York: Palgrave McMillan.

Torreiro, M. (1994), 'Un indulgente retrato generacional', El País, 17 August, p. 28.

Trashorras, A. (1998), 'Érase una vez en el barrio. perros callejeros y navajeros en el cine español de los 70 y 80', in R. Cuerto (ed.), Los desarraigados en el cine español, Gijón: Festival internacional de Gijón, pp. 83-112. 


\section{CONTRIBUTOR DETAILS}

Vicente Rodríguez Ortega is an assistant professor in Media Studies at Universidad Carlos III de Madrid. He is the author of La ciudad global en el cine contemporáneo: una perspectiva transnacional and co-editor of Contemporary Spanish Cinema and Genre. He has written over two dozen scholarly essays in book collections and scientific journals. He produced and directed the feature-length documentary Freddy's as well as other short documentaries and video essays. He is a distracted flâneur.

Contact: Universidad Carlos III, calle Madrid 133, Edificio Ortega y Gasset, Despacho 17.2.67, Getafe, Madrid 28903, Spain.

E-mail: vrortega@hum.uc3m.es 